\title{
Framework for Investigation of Karst Aquifer in an Arid Zone, Using Isotopes, Remote Sensing and GIS Applications: the Northwestern Coast of Egypt
}

\author{
Mohamed Yousif • Takashi Oguchi • Katsuro Anazawa • \\ Takeshi Ohba
}

Received: 17 July 2014 / Accepted: 21 January 2015 / Published online: 7 February 2015

(C) Springer International Publishing Switzerland 2015

\begin{abstract}
The hydrogeology of arid regions is becoming increasingly important due to diminishing projections of water resource availability in response to global environmental change. This paper aims to investigate the karst aquifer in the study area and clarifies the different factors which affect the occurrence and quality of its groundwater. The fractures systems are the main factor which controls the groundwater occurrence in the studied aquifer. The isotope analyses reveal that the groundwater has nearly similar isotopic compositions, suggesting similar recharge conditions; they also indicate that the groundwater of karst aquifer is meteoric water and the recharging source is the rainfall. The high values of total dissolved salts (TDS) of the groundwater are attributed to the rock-water interactions which lead to dissolution processes of marine salts into the aquifer matrix. Although most of the water levels in the drilled wells are under the sea level, the isotope analyses indicate that no contribution of seawater intrusion affects the groundwater. The present study reveals that some specific regions have more priorities than others in future groundwater explorations.
\end{abstract}

Keywords Egypt $\cdot$ Karst aquifer $\cdot$ Hydrogeology $\cdot$ Isotopes $\cdot$ Remote sensing and GIS

M. Yousif $(\bowtie)$

Geology Department, Desert Research Center, P.O.B. 11753, Cairo, Egypt

e-mail: yousif_mohamed80@daad-alumni.de

T. Oguchi

Center for Spatial Information Science, The University of Tokyo, 5-1-5 Kashiwanoha, Chiba 277-8563, Japan

K. Anazawa

Graduate School of Frontier Sciences, The University of Tokyo, 5-1-5 Kashiwanoha, Chiba 277-8563, Japan

T. Ohba

Department of Chemistry, Schools of Science, Tokai University, 4-1-1 Hiratsuka, Kanagawa 259-1292, Japan 


\section{Introduction}

Water availability in Egypt, as in other arid countries, is highly constrained due to many reasons, such as a fixed national share of the Nile River and population growth. The increasing demand for water and over-exploitation of the existing reserves has encouraged the studying of groundwater as a vital source for agricultural and developmental activities in the Northwestern coast (Embaby and Shanab 2012). The purposes of land reclamation and water resources development are to increase the scarce Egyptian farmland and help feed the Egypt's expanding population (Pautsch and Abdelrahman 1998). The major challenge which Egypt faces today is the need for better development and management of natural resources, to meet the needs of a growing nation. The northwestern coast of Egypt, overlooking at the Mediterranean Sea, is the part of the Western Desert that witnessed the end of the Second World War; several trials have been made there to provide the needed water through rainwater harvesting but the amount of water is insufficient (Ali et al. 2007). Therefore, groundwater becomes the most reasonable resource that is capable to supply or, at least, to supplement the other resources in providing the Northwestern coast with the needed water. Groundwater scarcity is, in many cases, accompanied by poor groundwater quality, especially in coastal aquifers, where water is often saline, and this leads to the reduction of its utility (El Raey 1998). Groundwater quality deterioration occurs in many parts of the southern Mediterranean coast, due to contamination in recharge areas, mismanagement during irrigation practice and over-exploitation of the coastal aquifers (Mediterranean Groundwater Report M.G.R. 2007). Accordingly, it is useful to intensify the exploration for groundwater in that particular area. Exploration for groundwater in such areas needs special planning in view of the prevailing geological and hydrogeological conditions. This means that the exploration process should depend on reliable information. Integration of remote sensing, geographical information systems (GIS), and isotope analyses ensures providing better information about the hydrogeological setting. The present study focusses on the karst aquifer which can be considered the main aquifer in the Northwestern coastal zone of Egypt which is represented by the Middle Miocene aquifer. The karst aquifer includes valuable water resources, which sometimes are difficult to exploit and are always vulnerable to contamination, due to the specific hydrogeologic properties (International Association of Hydrogeology IAH 2009). Therefore, the karst aquifer requires increased protection and application of hydrogeologic methods for its investigation. Other problems frequently encountered in karst areas include: soil erosion, rock desertification, leakages of channels and reservoirs, collapse of underground cavities and formation of sinkholes, and flooding (International Association of Hydrogeology IAH 2009). Lloyd (1997) stated that water policy of arid zone countries (such as Egypt) should be developed in relation to renewable water resources, and with careful studies and management, many arid countries will be able to use resources in the future without major restructuring.

The main objective of the current paper is to investigate the karst aquifer in the study area and clarify the different factors which affect the occurrence and quality of its water. Also, the current research aims to describe the hydrogeological situation and make recommendations concerning the future explorations of the studied aquifer. The study area occupies a portion of the Mediterranean coastal zone, where regional geomorphological studies of the Northwestern coastal zone have been carried out by many authors, such as: Hammad (1966), El Shamy (1968), Selim (1969), Misak (1974), Rizk (1982), and Hammad et al. (1986). The stratigraphy of different localities along the Mediterranean coastal zone has been described in the works of Said (1962) and El Shazly (1964, 1972). Hammad (1966, 1972) discussed the geology of different localities along the Northwestern coastal zone. El Senussi and Shata (1969), Misak (1974) and Mousa (1976) studied subsurface geology in some areas along the coast. On the 
other hand, the hydrogeology and the water resources of the Northwestern coastal zone have been studied by Paver and Protorius (1954), Atwa (1979) and Abdel Mogheeth (1968) who concentrated on the hydrogeology and hydrochemistry, while Ball (1939) studied the water supply of Marsa Matrouh city. The water resources in different wadis along the Northwestern coastal zone have been investigated by: Raslan (1995); Yousif and Bubenzer (2013a); Yousif and Bubenzer (2013b); Yousif (2014) and Yousif et al. (2014). Salem and Mohamed (2011) studied the hydrogeology in a depression located to the west of the study area, where the main aquifer belongs to Middle Miocene. From the above mentioned previous works, it is clear that great deals of efforts have been given to the regional geology and hydrogeology of the Northwestern coast; on the other hand, detailed information about the karst aquifer has been given through a few numbers of scattered wells. Therefore, the present study aims to provide information in the lights of the new drilling activities.

\section{The Study Area}

\subsection{General Description and Climate}

The study area occupies a portion of the Northwestern coastal zone of Egypt, which is an accessible area attaining promising lands for agricultural expansion beyond the Nile Valley and Delta. According to FAO (1989), the Northwestern coast of Egypt falls in the arid zone, which is characterized by pastoralism and no farming except with irrigation; the native vegetation is sparse, comprising annual and perennial grasses and other herbaceous vegetation, with annual amounts of rainfall ranging between 100 and $230 \mathrm{~mm}$. The study area is located from the west of Matrouh city (the capital of the Northwestern coast) to Sidi Barrani area (about $45 \mathrm{~km}$ to the east of the Egyptian-Libyan boarder), as shown in Fig. 1. In the present research, two pilot areas were chosen from the Northwestern coast: the first pilot area is El Negila which is bounded by longitudes $26^{\circ} 30^{\prime}$ and $27^{\circ} 5^{\prime} \mathrm{E}$, and latitudes $31^{\circ} 10^{\prime}$ and $31^{\circ} 30^{\prime} \mathrm{N}$, and covers approximately $1200 \mathrm{~km}^{2}$, and the second pilot area is Sidi Barrani which is bounded by longitudes $25^{\circ} 34^{\prime}$ and $26^{\circ} 13^{\prime} \mathrm{E}$ and latitudes $31^{\circ} 14^{\prime}$ and $31^{\circ} 40^{\prime} \mathrm{N}$, and covers approximately $2800 \mathrm{~km}^{2}$. The climatic conditions of the study area are typically arid, characterized by a long hot dry summer, mild winter with little rainfall, high evaporation with moderately to high relative humidity. Ali et al. (2007) described the climate of the Northwestern coast of Egypt for a long time period (1942-1992) as follows: the mean annual rainfall is $155 \mathrm{~mm}$ with a coefficient of variation of 0.42 ; the annual maximum and minimum temperatures are $24.4^{\circ} \mathrm{C}$ and $14.4{ }^{\circ} \mathrm{C}$ and the mean annual evapotranspiration is $1578 \mathrm{~mm}$. He stated that, according to the UNESCO (1977) criteria for characterization of semi-arid, arid and hyper arid zones, the two pilot areas in the present study fall in the arid environment (arid index for the study area, Precipitation $(\mathrm{P}) /$ Evaporation $(\mathrm{E})=0.09)$.

\subsection{Geomorphological and Geological Settings}

Geomorphollogically, the study area can be distinguished into three different geomorphologic units: the coastal plain, the piedmont plain and the tableland (Fig. 2a). The coastal plain occupies a narrow strip of land stretching adjacent to the Mediterranean Sea, its elevation ranges between 0 and $30 \mathrm{~m}$ above sea level with northward slope. The maximum inland extension of this plain is about $5 \mathrm{~km}$ from the sea, north to south direction. The coastal plain displays different landforms along the different segments, being influenced by the local structures (El Shazly and Shata 1971). Generally, it slopes in the northward direction, 


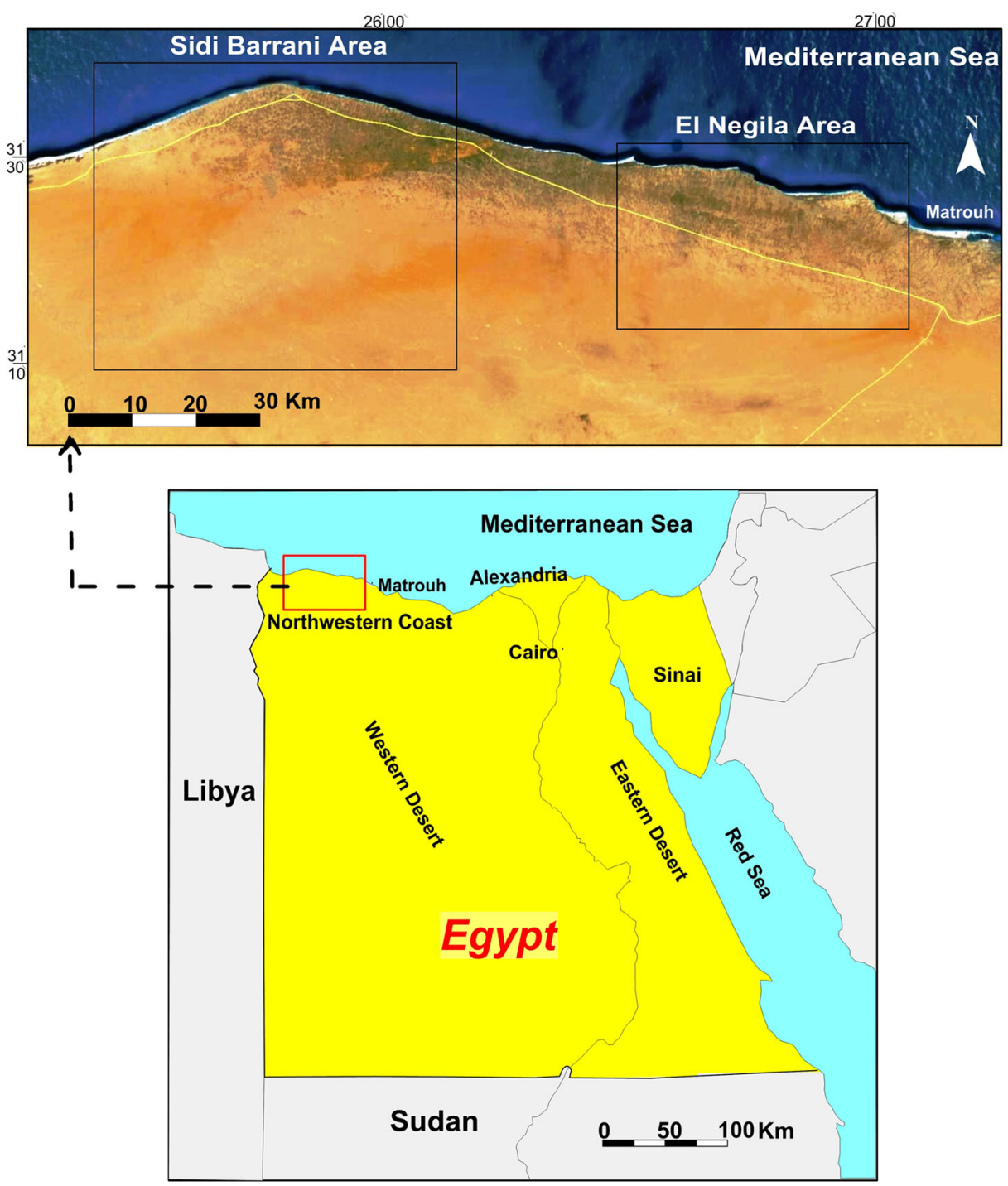

Fig. 1 Key map of the study area

exhibiting elevations varying from 0 to $50 \mathrm{~m}$ above sea level. The landscape of the coastal plain is influenced by several landforms, which include elongated ridges, dunes and shallow depressions (Raslan 1995). The piedmont plain extends to the south of the coastal plain as a zone between the tableland and the coastal plain, where its elevation ranges between 30 and $90 \mathrm{~m}$ above sea level. The width of the piedmont plain varies between 2 and $25 \mathrm{~km}$. This plain contains inland depressions between the ridges (El Shazly 1964). A hug depression is located to the west of the study area which receives many drainage lines; its floor elevation ranges between 0 and $30 \mathrm{~m}$ above sea level. The piedmont plain allows most of the surface runoff to be directed northwards into a lower gradational piedmont and/or the coastal plain. The tableland surface attains a maximum elevation of $250 \mathrm{~m}$ above sea level. The tableland is 
a
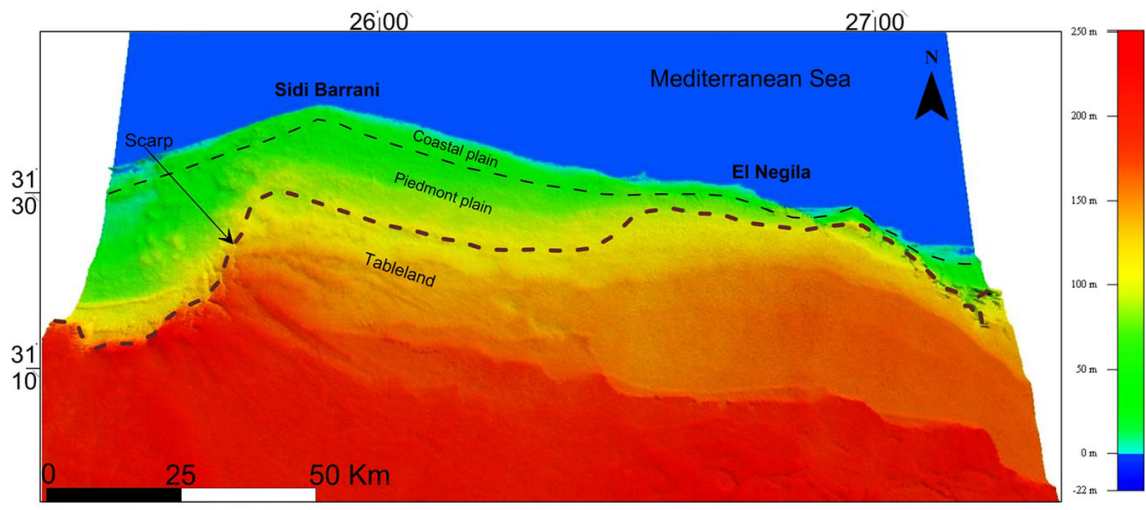

b

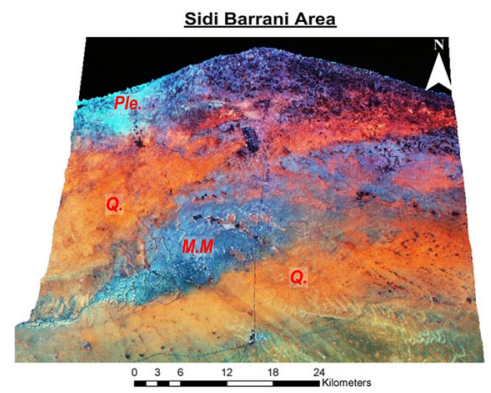

EI Negila Area

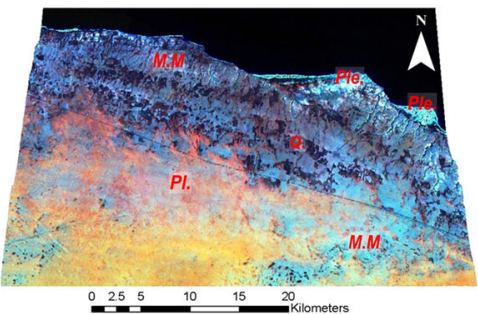

C
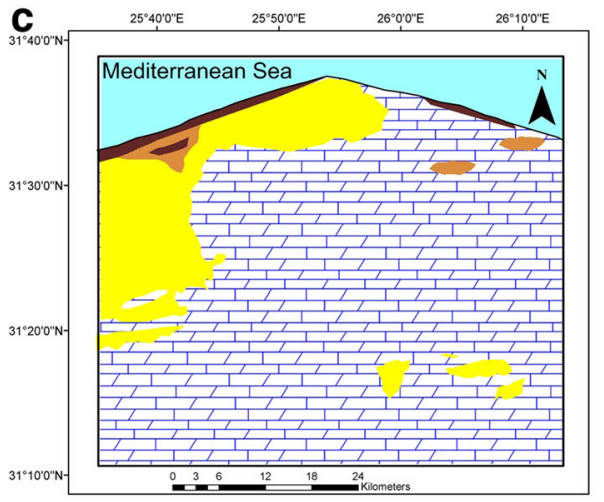

Legend
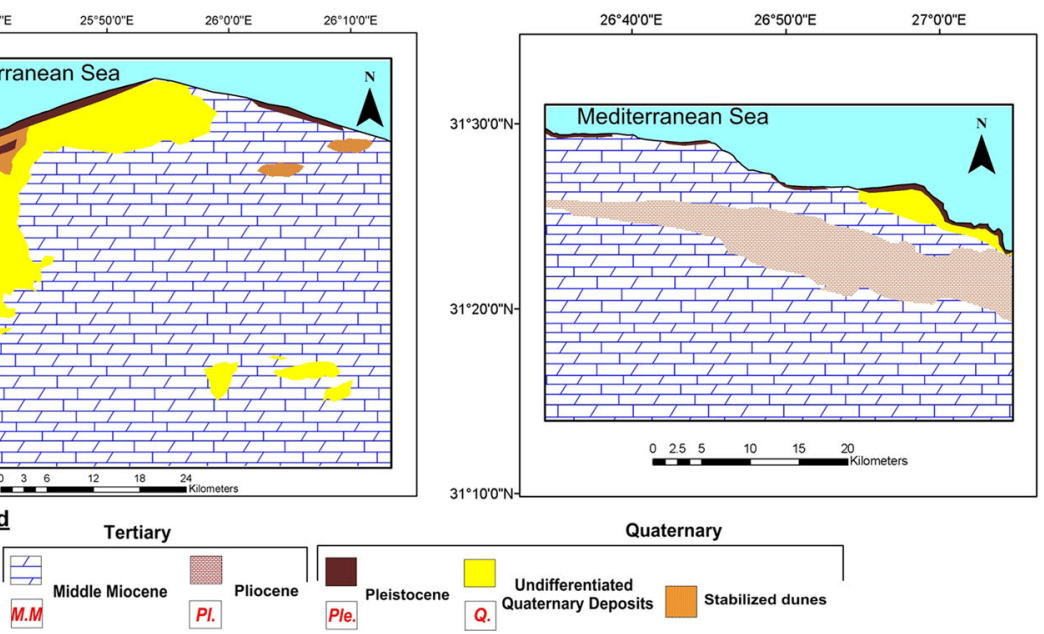

Quaternary

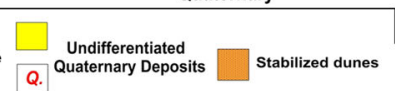

Fig. 2 Geomorphology and geology of the study area. a The main geomorphologic units of the study area (3-D view created from SRTM data); b Investigated landsat images showing the main rock units (GeoCover ETM+ 2000 with spatial resolution $15 \mathrm{~m}$, band combinations; 247); c Geology maps of the two pilot areas, derived from landsat image, field investigation and Conoco geologic map (1986)

bound by scarp (100 m above sea level) facing the piedmont plain (Shata 1957). This geomorphic unit represents the principal watershed area; it slopes to the north and east directions, which allows surface runoff to be directed through the drainage basin to the Mediterranean Sea. 
Geologically, the area under investigation is located in an unstable shelf which differs stratigraphically from the stable one in being thinner and more distributed (Said 1990). The exposed rocks in the study area are entirely of sedimentary origin ranging in age from the Middle Miocene to Quaternary (Fig. 2b and c). The Middle Miocene is represented by Marmarica limestone formation which covers the most parts of the study area. This formation is made up of an upper white limestone fossilfereous member, middle snow white chalk member and a lower member of alternating cross bedded carbonates, shale and marls (Raslan 1995). It changes laterally from chalky marly limestone to sandy and clay facies at the approach of headland (Hammad 1972). The Pliocene sediments are of limited distribution in the area of investigation. The lower part of Pliocene succession is formed of creamy limestone and its upper part of brown calcareous sandstone (Raslan 1995). The Quaternary sediments include Pleistocene and Holocene deposits. Pleistocene sediments are widely distributed in the study area along the Mediterranean Coast. They are mainly represented by oolitic limestone, which constitutes the main bulk of the Pleistocene sediments and is almost developed in the form of elongated ridges running parallel to the present coast (Yousif and Bubenzer 2013a, 2013b). The Holocene non-consolidated deposits have a wide spread and consist, essentially, of weathering products of the Miocene and Pleistocene deposits, which are represented by several varieties of different lithological characters, i.e., beach, alluvial and aeolian deposits (Selim 1969).

The structure of the Northwestern coastal zone is dominated by folds and faults, with most folds formed during Late Cretaceous - Early Tertiary, and have NE-SW direction that agrees with the Syrian Arc system trend (Shata 1957; Said 1962). As a result of this trend, local plunging anticlines were developed consisting of headland protruded into the sea along the coast in the study area. The headlands are separated by a series of synclinal basins having the same trend (Shata 1955). Shata (1953) stated that the structures were formed primarily by rotational stresses during several stages, starting since the Middle Cretaceous, and continued throughout the Tertiary and probably through the Quaternary.

\section{Data and Methodology}

\subsection{Field Work}

The field work started in May 2012 and comprised an inventory survey for existing 40 groundwater wells with identification of factors which affect the occurrence and quality of groundwater in the studied aquifer in the two pilot areas. Hydrogeological data were also determined and measured (e.g., depth to water, total depth, water-bearing formations and hydro-geomorphologic units). Also, the subsurface succession of some wells was obtained during their drilling stage, which was used in constructing the hydrogeological cross sections in combination with surface lithology.

\subsection{Chemical and Isotope Analyses of the Groundwater Samples}

Forty two samples (40 groundwater samples, plus 2 samples from rain to sea) were analyzed in the central laboratory of the Desert Research Center (DRC) according to the American Society of Testing and Materials standard methods (ASTM 2002). Geochemical representations of the chemical analyses of the studied groundwater samples were carried out to clarify the relationships between different elements, such as iodide and bromide, as well as chloride and sodium, and to identify the genesis of the groundwater by using Piper diagrams (Piper 1944). In 
addition, major element data were used to confirm the source of the groundwater, using the concentration rate $(\mathrm{CR})$ and Enrichment factor $(\mathrm{EF})$ relative to chloride of seawater. The concentration ratio (CR) of $\mathrm{Cl}^{-}$in the studied groundwater in relation to its concentration in seawater indicates the mixing rate of seawater and meteoric water. The chloride is chosen as indicator for sea intrusion, since seawater solutes are specifically characterized by excess $\mathrm{Cl}^{-}$. Also, the Enrichment factor (EF) is calculated to show the degree of enrichment of a given common element (i.e., $\mathrm{Mg}^{2+}, \mathrm{Na}^{+}$) compared to the relative abundance of this element in seawater. The enrichment factor EF is defined as (Duce et al. 1975):

$$
E F(X)=\left(X / C l^{-}\right) \mathrm{rain} /\left(X / \mathrm{Cl}^{-}\right) \mathrm{sea}
$$

where: $\left(\mathrm{X} / \mathrm{Cl}^{-}\right)$rain is the ratio between substance $\mathrm{X}$ concentration and $\mathrm{Cl}^{-}$concentration in rainwater; and $\left(\mathrm{X} / \mathrm{Cl}^{-}\right)$sea is the ratio of substance $\mathrm{X}$ relative to $\mathrm{Cl}^{-}$in seawater.

In the present research, the isotopic analyses of the groundwater were investigated to establish whether there is additional recent recharge, since the exploitation of a nonrechargeable closed-system aquifer cannot be used for any future well extraction in a sustainable way. The stable isotopic data of hydrogen and oxygen $\left(\delta \mathrm{D}\right.$ and $\left.\delta^{18} \mathrm{O}\right)$ for a total of 47 samples were used in the present study. A total of 27 water samples ( 25 from groundwater, and two from local recent rainfall and the Mediterranean Sea) were subjected to isotope analyses, in addition to data for 20 rainfall samples (10 for each area) obtained from International Atomic Energy and "IAEA" (2004). Stable isotopes of oxygen and hydrogen $\left(\delta^{18} \mathrm{O}, \delta \mathrm{D}\right)$ were determined by Cavity Ring-Down Spectroscopy (CRDS) using a Laser Isotope Analyzer (Picarro L2120-i, $\mathrm{H}_{2} \mathrm{O}$ ). The determination was performed from water samples at the Department of Chemistry, Tokai University, Japan.

\subsection{Remote Sensing and Geographical Information Systems (GIS)}

The Shuttle Radar Topography Mission (SRTM) provides the basic data for the current research, as well as the satellite images (ETM+ and spots). The data from satellite images was employed for visual interpretation of surface features and geology of the study area. The SRTM processing started by constructing DEM mosaic to extract the watersheds of the study area. The hydrology tools of ArcGIS v.10 and Arc Hydro module (Maidment 2002) were employed to identify and fill all sinks in the resulting mosaic. The flow direction grid was extracted based on the D8 flow direction algorithm (Jensen and Domingue 1988), which is widely used in arid environments (Foody et al. 2004; Ghoneim 2008; Ghoneim and Foody 2012). Next, the drainage network was extracted by calculating the flow accumulation for each cell. The interpretation of the landsat image was done using ERDAS IMAGINE (ver. 9.3) where the images were first re-projected and subset to the study area, and then imported into the ESRI ArcMap GIS 10. Landsat GeoCover ETM+2000 (bands combinations 2, 4, and 7) with spatial resolution $15 \mathrm{~m}$, and spot images with different resolutions $(5,10,20 \mathrm{~m})$ were used with the geological map (1:500,000; Conoco 1986) to create a geology map of the study area. In addition, geological features, like faults, were easily seen in the bands, 754 and 741 of Enhanced Thematic Mapper (ETM+). These bands are the only bands which were used in the current study. First, an enhancement technique, like filtering, was applied, where the important field of filtering in image processing is the edge detection (through convolution filtering in ERDAS IMAGIN 9.3). Edge detection depends on variations of digital pixel values of the image. The spatial analysis of various data was carried out using the ArcGIS 10 software, in order to interpolate the data spatially and to convert the data to layers such as (geomorphology, geology, well locations, drainage lines, watersheds, flow directions, and structure lineaments). 
On the other hand, since hydrogeological evaluation associates with the rate of precipitation, detailed rainfall data during long and short periods were analyzed to achieve the current research. In the current research, 3 types of TRMM data were analyzed: the accumulated precipitation (mm) during the last 14 years, the TRMM Online Visualization and Analysis System (TOVAS) for the accumulated precipitation during the last rainy season, and the annual precipitation during 1 year (2012). Analyses and visualizations used in this study were produced with the Giovanni online data system, developed and maintained by the NASA GES DISC. Finally, two priority maps for both pilot study areas were prepared to clarify the applied concept of the current research and to show which regions are favorable for groundwater development, so that these regions be subjected to hydro-geophysical studies. The study area was subdivided to regions according to its priority for future explorations. These regions are determined on the basis of the data layers; structural lineaments, drainage basins, slope, and the data of the recent drilled wells of the karst aquifer (hydrogeologic data). Therefore, the two pilot study areas were assigned priority degrees ranging from first priority to fourth priority, where the areas with first priority for future explorations have the best conditions for groundwater occurrence in comparison to other areas.

\section{Results}

\subsection{Precipitation Data Estimated from Satellite}

The analyses of Tropical Rainfall Measuring Mission (TRMM) revealed the following results: The diagram of area average time series in the last 14 years (1998-2012) of the total precipitation shows the main events. The study area is subjected to multiple events every year with one in 2002 reaching $400 \mathrm{~mm}$ (Fig. 3a). The total precipitation ( $\mathrm{mm}$ ) is evaluated during the 14 years (from 1 January 1998 to 1 January 2012); most parts of El Negila area receive a total precipitation ranging between $2291 \mathrm{~mm}$ (annual average $163.64 \mathrm{~mm}$ ) and $2781 \mathrm{~mm}$ (annual average $198.64 \mathrm{~mm}$ ), while most parts of Sidi Barrani area have a total precipitation ranging between $2046 \mathrm{~mm}$ (annual average $146.14 \mathrm{~mm}$ ) and $2536 \mathrm{~mm}$ (annual average $181.14 \mathrm{~mm}$ ) (Fig. 3b). The map of TRMM Online Visualization and Analysis System (TOVAS) shows that the maximum total precipitation during the last rainy season before groundwater pumping (from 1 October 2011 to 1 March 2012) fell on the tableland which received $613 \mathrm{~mm}$ in El Negila area and $464.1 \mathrm{~mm}$ in Sidi Barrani area (Fig. 3c). On the other hand, the annual precipitation during 1 year (2012) had its maximum value in El Negila area (196.8 mm) and its value in Sidi Barrani area was $152.3 \mathrm{~mm}$ (Fig. 3d).

\subsection{Delineation of Structural Lineaments}

The delineation of structural lineaments of El Negila area shows that the main trend of lineaments is NE-SW followed by NW-SE and E-W directions (Fig. 4a and c). The contouring of lineament frequency of this area ranges between 0.05 and $0.18 \mathrm{~km}^{-2}$, with the structural lineaments concentrated in the vicinities of head lands in the northern parts of El Negila area (frequency ranges from 0.15 to $0.175 \mathrm{~km}^{-2}$ ). On the other hand, the structural lineaments of Sidi Barrani area have two trends: NE-SW and NW-SE and their frequency range between 0.016 and $0.052 \mathrm{~km}^{-2}$, with the lineaments mainly concentrated on the eastern part of the coast of Sidi Barrani area (Fig. 4b and d). The analyses of spot images show some more details for the study area. In El Negila area, it is clear that the area has two zones: the northern one (zone A) which is characterized by the presence of drainage lines of high density, and the southern 
a

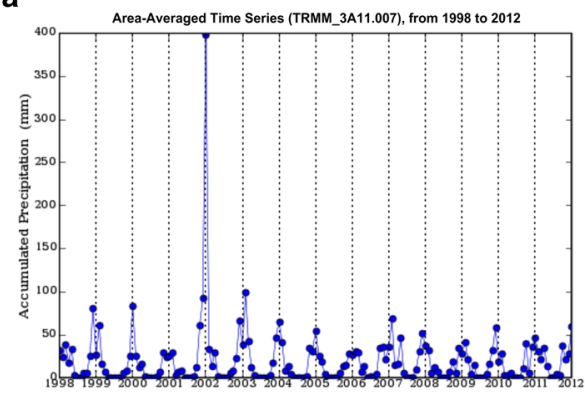

C

TRMM accumulated precipitation $(\mathrm{mm})$ during the rainy season, from 1 October to 2011 to 1 March 2012 b

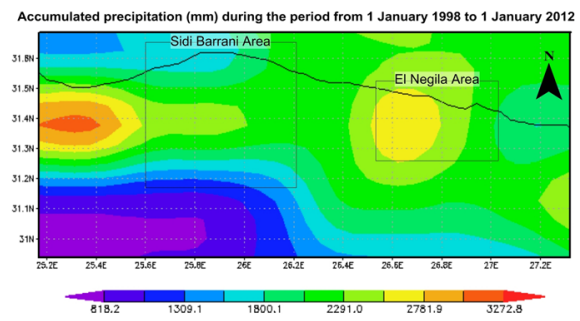

d

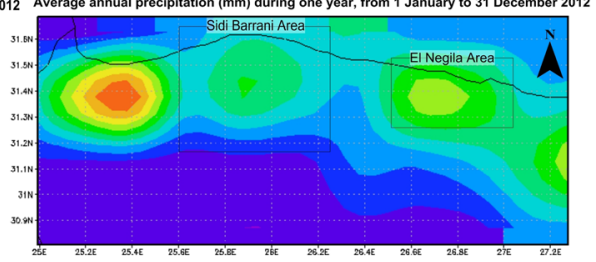

Fig. 3 Precipitation data estimated from satellite, TRMM (Tropical Rainfall Measuring Mission). a The main precipitation events: the study area is subjected to multiple events every year; b The accumulated annual precipitation (mm) during 14 years; c TRMM Online Visualization and Analysis System (TOVAS) shows the accumulated precipitation during the rainy season before the groundwater pumping in 2012; d TRMM Online Visualization and Analysis System (TOVAS) shows the accumulated precipitation during 1 year

one (zone B) which is characterized by smooth surface without drainage lines or hydrographic basins (Fig. 5a). The spot images clarify that El Negila area has 8 headlands inside the sea; these headlands represent the anticline structure while the area between two headlands represent the syncline structure (Fig. 5a). This local structure can be considered responsible for the density of drainage lines in zone A and disappearing of any lines in zone B, where anticline and syncline structures are accompanied by fractures and joints which facilitate the action of water and the formation of drainage lines. In Sidi Barrani area, the spot image gives more details for the depression located to the east of the area. This depression has a special location with many hydrographic basins located on its borders and drain to the depression; one of these basins with its tributaries cross the depression to the sea (Fig. 5b and c). These conditions facilitate the recharge of the groundwater, particularly where its surface is covered by friable sand.

\subsection{Extraction of the Drainage Lines and the Hydrographic Basins}

The extraction of the drainage lines and the hydrographic basins have resulted from the analyses of SRTM data and indicate that the two pilot areas are dissected by a number of wadis which flow generally from south to north with the natural slopes (Fig. 6). The density of drainage lines in El Negila area is higher than Sidi Barrani area. The slope values for the majority of the study area are less than $5^{\circ}$ which mean that the area is mainly plain. El Negila area has a slope ranging between 0 and $1.5^{\circ}$ in the southern parts (tableland); this slope increases to range between 1.5 and $7^{\circ}$ at the scarp and at the outlet of the drainage basins from the tableland, and reach its maximum values $\left(7-15^{\circ}\right)$ along some drainage lines at the 

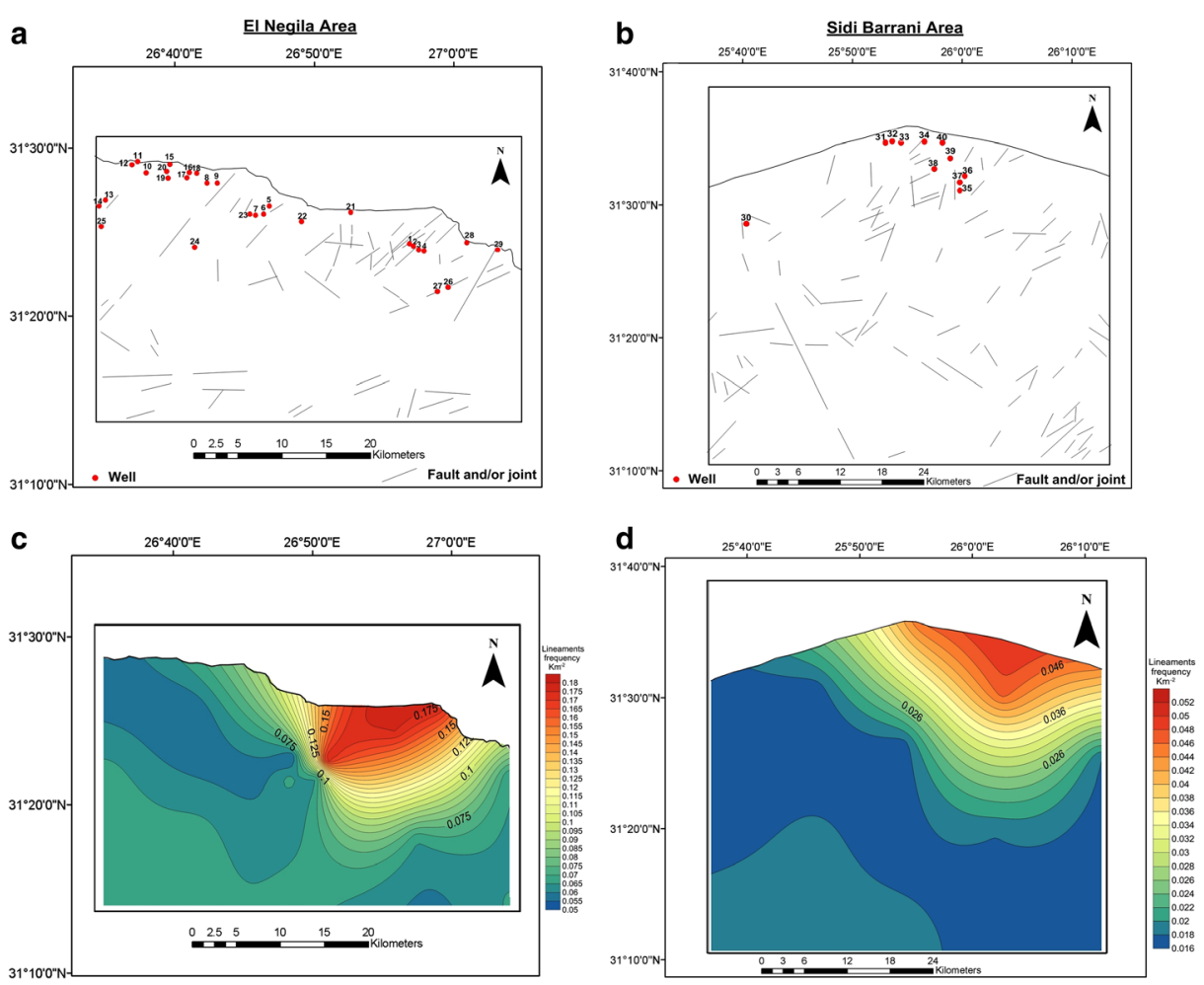

Fig. 4 Structural lineaments of the study area extracted from geologic map (Conoco 1986). (a) and (b) The lineaments and groundwater wells are plotted together, the two maps show that the wells were drilled in the areas which slightly affected by faults and fractures; (c) and (d) Two contour maps of the lineament frequency show which regions are most affected by structure lineaments. These layers are used to determine the priority for future groundwater explorations where the regions which have more structure lineaments have higher opportunities for recharge

northeastern part of the area (Fig. 6). On the other hand, the Sidi Barrani area is mainly plain where its slope values range between 0 and $1.8^{\circ}$ with the maximum values $\left(5-13^{\circ}\right)$ recorded at the boundary of the depression at the eastern part of the study area with many drainage lines draining to this depression (Fig. 6).

\subsection{Hydrogeologic Setting}

Recently (in 2009), new wells for groundwater exploration in the karst aquifer (Middle Miocene fractured limestone aquifer) were drilled. New data from 29 wells in the El Negila area and 11 wells in the Sidi Barrani area are presented in the current research (Fig. 7). In El Negila area, the total depth of the wells ranges between 5 and $100 \mathrm{~m}$, the water level ranges between -11.5 and $59 \mathrm{~m}$ from sea level, and TDS concentrations range between 1981 and $12,892 \mathrm{mg} / \mathrm{L}$ (Table 1). On the other hand, in Sidi Barrani area, the total depth of the wells ranges between 42 and $70 \mathrm{~m}$, the water level ranges between -7.7 and $7.13 \mathrm{~m}$ from sea level, and TDS concentrations range between 1427 and 23,951 mg/L (Table 1). In El Negila area, well numbers $26,27,24,25,1,2,3$ and 4, drilled on the tableland, have a water level above the sea level, while the wells drilled on the piedmont and coastal plains have a water level equal to 


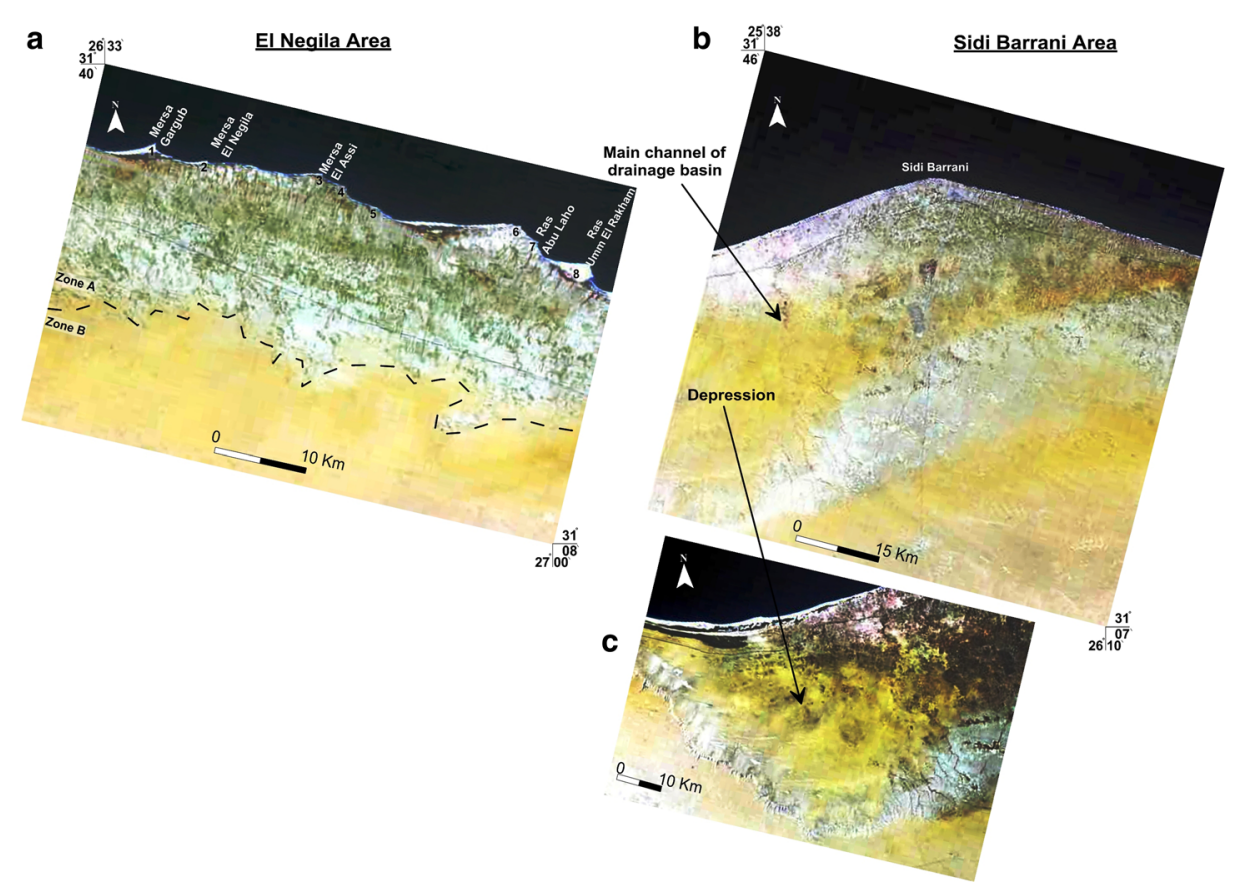

Fig. 5 Spot images of the study area. a Spot image of El Negila area (spot 4, resolution $10 \mathrm{~m}, 3$ spectral bands: 1, 2 and 3,2011). The image shows two zones: zone A characterized by the presence of drainage lines, and zone B characterized by smooth surface with no drainage lines or hydrographic basins. In addition, 8 headlands are recorded along the coast of El Negila area; b Spot image of Sidi Barrani area (spot 5, resolution 5 m, 3 spectral bands: 1, 2 and 3,2011), shows a depression located to the east of the area. This depression has special location where many hydrographic basins are located on its borders and drain to the depression, and one of these basins with its tributaries cross the depression to the sea; c Spot image (spot 4, resolution $20 \mathrm{~m}, 4$ spectral bands: 1, 2, 3 and SWIR, 2012), focusing on the depression where drainage lines surround it from 3 sides, a condition that facilitates the recharge of groundwater, particularly where its surface is covered by friable sand

or below the sea level. In Sidi Barrani area, only the wells with numbers 35 and 38 have a water level above the sea level (drilled in the tableland), while the other wells have a water level below the sea level. The hydrogeological cross sections of El Negila and Sidi Barrani areas (Fig. 8) indicate that there are possibilities for groundwater recharge from the rainfall, with rain falling on the highlands (tableland) and flow to the Mediterranean Sea to the north. The opportunities of recharge are possible because the rocks of the karst aquifer are mainly fractured and recharge is increased along the drainage lines (in the wadis) where these drainage lines act as water collectors (this is the case of wells with numbers 26, 28 and 40). Also, a claystone layer exists in well no. 24 at a depth equal to sea level; this layer was recorded in a limited number of wells (only in El Negila area) which clarify that it is a lens of claystone.

\subsection{Isotope Analyses}

The isotopic ratios $\left(\delta \mathrm{D}\right.$ and $\left.\delta^{18} \mathrm{O}\right)$ of the recent local rainfall reach $-7.48 \%$ for $\delta \mathrm{D}$ and $-3.47 \%$ for $\delta^{18} \mathrm{O}$, and the ratios for the seawater in the study area reach $10.16 \%$ for $\delta \mathrm{D}$ and $1.54 \%$ for $\delta^{18} \mathrm{O}$. The isotopic ratios for the groundwater samples of the karst aquifer in both pilot areas are shown in Table 2. The isotopic data of the collected water samples, as well as 

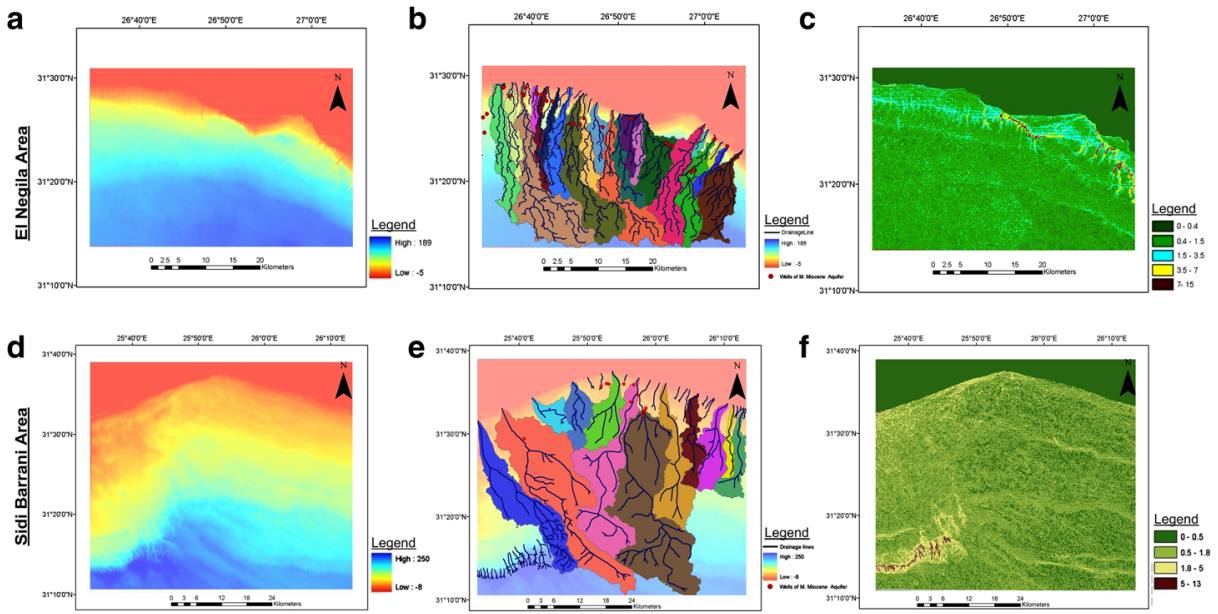

Fig. 6 Hydrographic basins and slope layers of the two pilot areas. (a) and (d) Digital elevation modeling (SRTM), which represents the base layer in the processing of drainage lines extraction; (b) and (e) Hydrographic basins and drainage lines, automatically extracted from SRTM data. The groundwater wells of karst aquifer were plotted over this layer; (c) and (f) The slope layer, extracted from SRTM data

the isotopic data of rainfall (International Atomic Energy and "IAEA" 2004) were plotted on $\delta \mathrm{D}-\delta^{18} \mathrm{O}$ diagram (Fig. 9a and b). The scattering of $\delta \mathrm{D}-\delta^{18} \mathrm{O}$ diagram reveals that the samples from the karst aquifer in the two pilot areas fall within the isotopic range of local precipitation (recent sample, 2012) and also within the rainfall samples from 1994 to 2003. Also, the diagrams show that all the studied groundwater samples fall near or above the Alexandria local meteoric water line (ALMWL; Awad et al. 1994). The deuterium excess (dexcess $=\delta \mathrm{D}-8 \delta^{18} \mathrm{O}$; Dansgaard 1964) is calculated in the present study (Table 2), and ranges between 9.67 and $18.52 \%$ in El Negila area and between 11.92 and $16.03 \%$ in Sidi Barrani area. The d-excess value for the local rainfall is $20.27 \%$ and for local seawater is $-2.21 \%$.

To get more information for different types of water, the chloride values of water samples was plotted versus $\delta^{18} \mathrm{O}$ in Fig. 9d. The plot reveals that the groundwater samples are close to
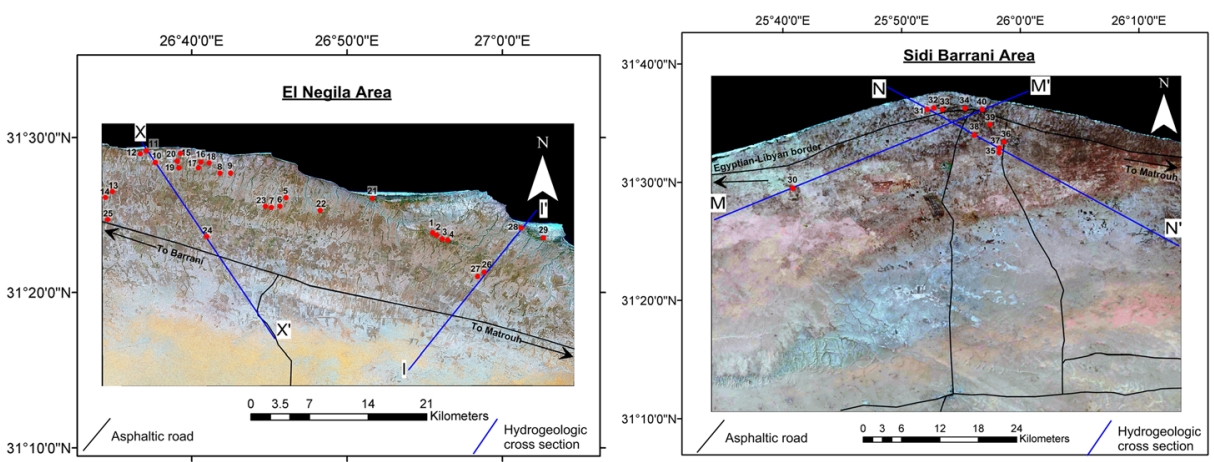

Fig. 7 Wells location maps, the wells sites have been placed on the landsat images (GLS landsat, global land survey, ETM+2010). The maps include the locations of the four hydrogeological cross sections; (X-X and I-I) in El Negila area and (M-M and N-N ) in Sidi Barrani area 
Table 1 Hydrogeological data of the wells tapping the karst aquifers

\begin{tabular}{|c|c|c|c|c|c|c|c|c|}
\hline Area & $\begin{array}{l}\text { Well } \\
\text { No. }\end{array}$ & Long East & Lat. North & $\begin{array}{l}\text { Total } \\
\text { Depth }\end{array}$ & $\begin{array}{l}\text { Depth to water } \\
\text { from ground }\end{array}$ & $\begin{array}{l}\text { Ground elevation } \\
\text { from sea level }\end{array}$ & $\begin{array}{l}\text { Water level } \\
\text { from sea level }\end{array}$ & $\begin{array}{l}\mathrm{TDS} \\
\mathrm{mg} / \mathrm{L}\end{array}$ \\
\hline \multirow[t]{29}{*}{ El Negila } & 1 & 26.925528 & 31.394972 & 100 & 89 & 96 & 7 & 1981 \\
\hline & 2 & 26.92975 & 31.3925 & 100 & 89 & 95 & 6 & 2042 \\
\hline & 3 & 26.93075 & 31.391917 & 100 & 89 & 95 & 6 & 4394 \\
\hline & 4 & 26.937944 & 31.388889 & 100 & 89 & 94 & 5 & 4308 \\
\hline & 5 & 26.767389 & 31.433583 & 80 & 56 & 65.5 & 9.5 & 4510 \\
\hline & 6 & 26.760444 & 31.423639 & 85 & 78 & 77 & -1 & 4814 \\
\hline & 7 & 26.748556 & 31.424361 & 100 & 80 & 76.5 & -3.5 & 4256 \\
\hline & 8 & 26.695972 & 31.460417 & 40 & 38 & 42.9 & 4.9 & 6814 \\
\hline & 9 & 26.7075 & 31.460333 & 40 & 38 & 38.5 & 0.5 & 7441 \\
\hline & 10 & 26.626056 & 31.468806 & 50 & 36 & 36 & 0 & 6162 \\
\hline & 11 & 26.613556 & 31.482861 & 16 & 12 & 12.73 & 0.73 & 12,186 \\
\hline & 12 & 26.612278 & 31.481222 & 20 & 16 & 11.5 & -4.5 & 11,919 \\
\hline & 13 & 26.580694 & 31.439667 & 90 & 80 & 76.5 & -3.5 & 5713 \\
\hline & 14 & 26.573194 & 31.434417 & 120 & 95 & 83.5 & -11.5 & 4911 \\
\hline & 15 & 26.654611 & 31.481528 & 25 & 16 & 16.2 & 0.2 & 8537 \\
\hline & 16 & 26.676861 & 31.472167 & 42 & 32 & 26.7 & -5.3 & 8704 \\
\hline & 17 & 26.67675 & 31.471528 & 42 & 32 & 27.15 & -4.85 & 7554 \\
\hline & 18 & 26.685083 & 31.470778 & 45 & 24.5 & 26 & 1.5 & 2551 \\
\hline & 19 & 26.651556 & 31.468972 & 40 & 36 & 34 & -2 & 6487 \\
\hline & 20 & 26.650722 & 31.471556 & 40 & 30 & 31.5 & 1.5 & 12,892 \\
\hline & 21 & 26.859444 & 31.433417 & 10 & 4.8 & 4.4 & -0.4 & 4195 \\
\hline & 22 & 26.803833 & 31.419444 & 100 & 80 & 82.8 & 2.8 & 3655 \\
\hline & 23 & 26.745583 & 31.42475 & 100 & 80 & 79 & -1 & 2243 \\
\hline & 24 & 26.682861 & 31.391944 & 100 & 97 & 110.2 & 13.2 & 6842 \\
\hline & 25 & 26.57625 & 31.409917 & 100 & 90 & 102.5 & 12.5 & 5823 \\
\hline & 26 & 26.979167 & 31.352333 & 60 & 50 & 109 & 59 & 4131 \\
\hline & 27 & 26.974444 & 31.348806 & 70 & 58 & 117 & 59 & 2324 \\
\hline & 28 & 27.019667 & 31.400889 & 17 & 8 & 4.9 & -3.1 & 4296 \\
\hline & 29 & 27.043222 & 31.389278 & 5 & 4 & 6.6 & 2.6 & 5763 \\
\hline \multirow{11}{*}{$\begin{array}{l}\text { Sedi } \\
\quad \text { Barrani }\end{array}$} & 30 & 25.681611 & 31.491556 & 55 & 31 & 31 & 0 & 2905 \\
\hline & 31 & 25.867861 & 31.598278 & 50 & 45 & 37.3 & -7.7 & 17,784 \\
\hline & 32 & 25.880806 & 31.603806 & 40 & 35 & 32 & -3 & 20,143 \\
\hline & 33 & 25.887083 & 31.602861 & 45 & 39 & 34.5 & -4.5 & 23,951 \\
\hline & 34 & 25.923111 & 31.603361 & 40 & 30 & 30 & 0 & 5151 \\
\hline & 35 & 25.970694 & 31.54175 & 70 & 40 & 43.76 & 3.76 & 1427 \\
\hline & 36 & 25.977389 & 31.556139 & 60 & 48 & 41.5 & -6.5 & 8879 \\
\hline & 37 & 25.97325 & 31.550694 & 70 & 50 & 45.3 & -4.7 & 5488 \\
\hline & 38 & 25.939833 & 31.568333 & 42 & 36 & 43.13 & 7.13 & 14,987 \\
\hline & 39 & 25.958861 & 31.581306 & 63 & 35 & 32.7 & -2.3 & 15,429 \\
\hline & 40 & 25.947194 & 31.601806 & 35 & 24 & 24 & 0 & 11,963 \\
\hline
\end{tabular}

the rainwater sample with different $\mathrm{Cl}^{-}$values in both pilot areas, which indicates different mixing percentages with rainfall and no evidences of mixing with seawater. 

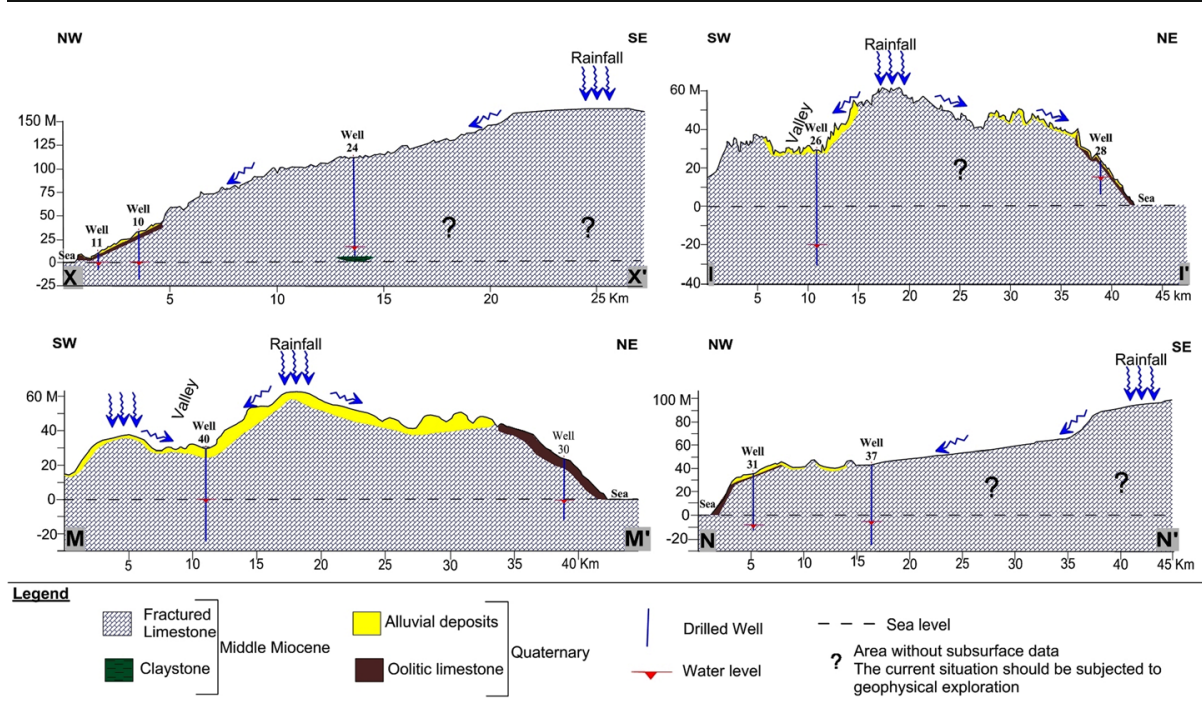

Fig. 8 Hydrogeological cross sections in the study area, showing the recharge opportunities from the rainfall and the subsurface succession of the karst aquifer. (X-X and I-I ) in El Negila area and (M-M and N-N) in Sidi Barrani area. The locations of these cross sections are illustrated in the well location maps

\subsection{Chemical Analyses}

The ratio $\left(\Gamma^{-} / \mathrm{Br}^{-}\right)$is of particular importance since both iodide and bromide ions characterize the chemistry of waters having marine contamination. The ranges values of $\mathrm{Br}^{-}$and $\mathrm{I}^{-}$concentrations in groundwater samples of the studied aquifers are shown in Table 2 and Fig. 10a. These values are very low with respect to seawater $\left(\mathrm{Br}^{-}=310 \mathrm{mg} / \mathrm{L}\right.$ and $\left.\Gamma^{-}=0.34 \mathrm{mg} / \mathrm{L}\right)$ and very close to rainwater $\left(\mathrm{Br}^{-}=0.56 \mathrm{mg} / \mathrm{L}\right.$ and $\left.\Gamma^{-}=0.0048 \mathrm{mg} / \mathrm{L}\right)$. This reflects that the groundwater mineralization of the studied aquifers is of meteoric origin (rainfall), which confirms the results obtained from isotope analyses. Because sodium and chloride ions enter any solution at equal quantities during the dissolution of halite, an approximately linear relationship (unity line) may be observed between these ions. The plot of sodium against chloride concentration (Fig. 10b) shows that the groundwater samples from both aquifers fall close to unity line $\left(\mathrm{Na}^{+} / \mathrm{Cl}^{-}=1\right)$, and also close to the rainfall sample, which indicates meteoric water in origin without significant addition or loss of $\mathrm{Na}^{+}$. In the Piper diagram, the groundwater evolves to sodium chloride facies, where all the groundwater of karst aquifers in both pilot areas is characterized as $\mathrm{Na}-\mathrm{Cl}$ type. The Piper diagram (Fig. 10c) indicates that the groundwater of karst aquifer is chloriderich in the anions triangle, while they are all located in the alkali- $(\mathrm{Na}+\mathrm{K})$ rich field. The diamond-shaped field shows that all the groundwater samples are located in the field of Na-K and $\mathrm{Cl}-\mathrm{SO}_{4}$ water type, indicating secondary salinity properties which can be attributed mainly to dissolution of salts in the water-bearing deposits.

The concentration ratios $(\mathrm{CR})$ of $\mathrm{Cl}^{-}$may indicate mixing rate of seawater and meteoric water, and the obtained isotopic data confirms that the groundwater is mainly meteoric water. Therefore, the values of the chloride concentration ratios (Table 3) show that the groundwater of karst aquifer in the El Negila area has CR values mainly less than $0.25 \mathrm{mg} / \mathrm{L}$, and in the Sidi Barrani area, the values are slightly increased to reach $0.47 \mathrm{mg} / \mathrm{L}$. This indicates that the groundwater of the karst aquifer in El Negila area was not affected by seawater. On the other hand, this influence is more pronounced in Sidi Barrani area, particularly in the coastal wells. 


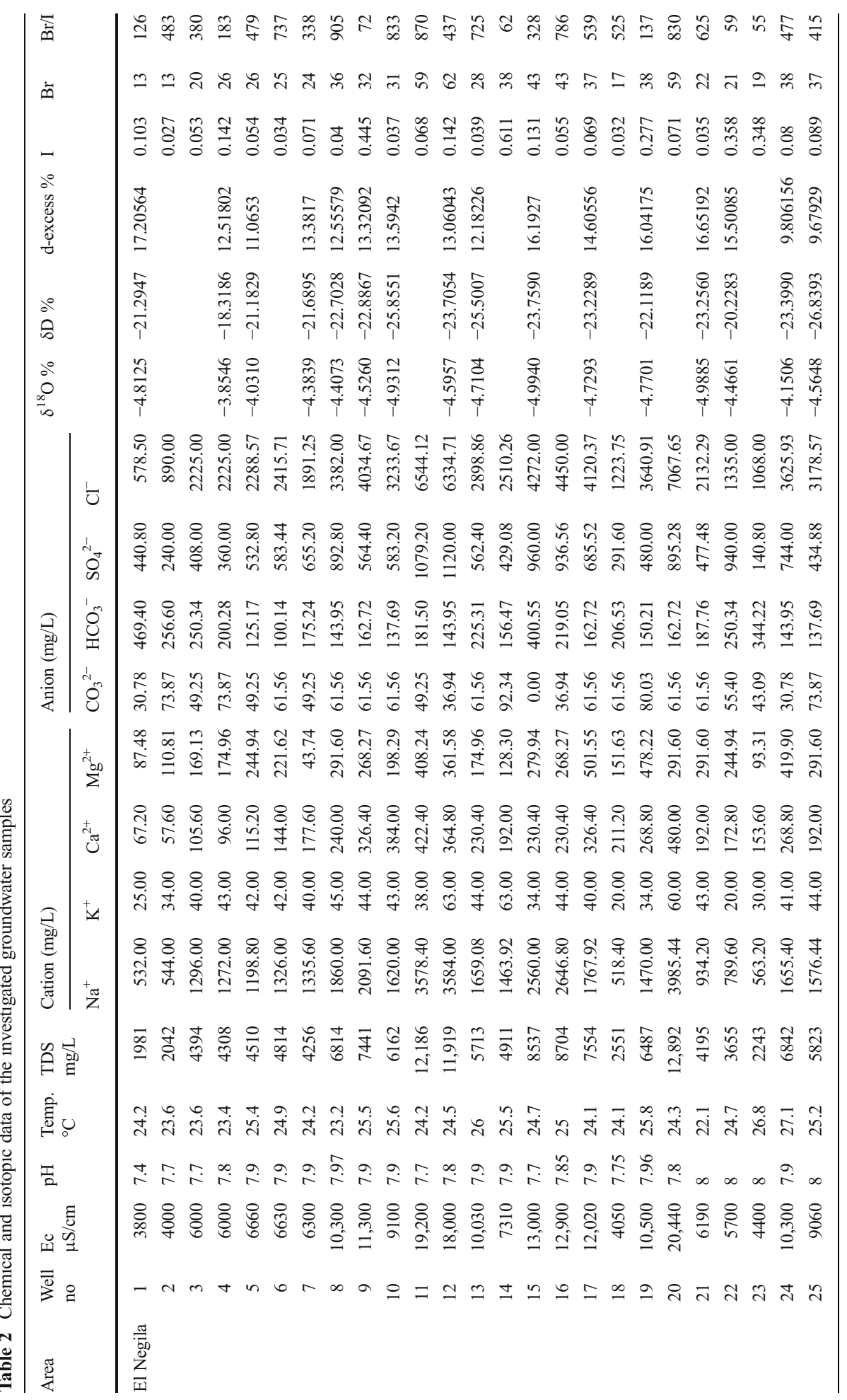




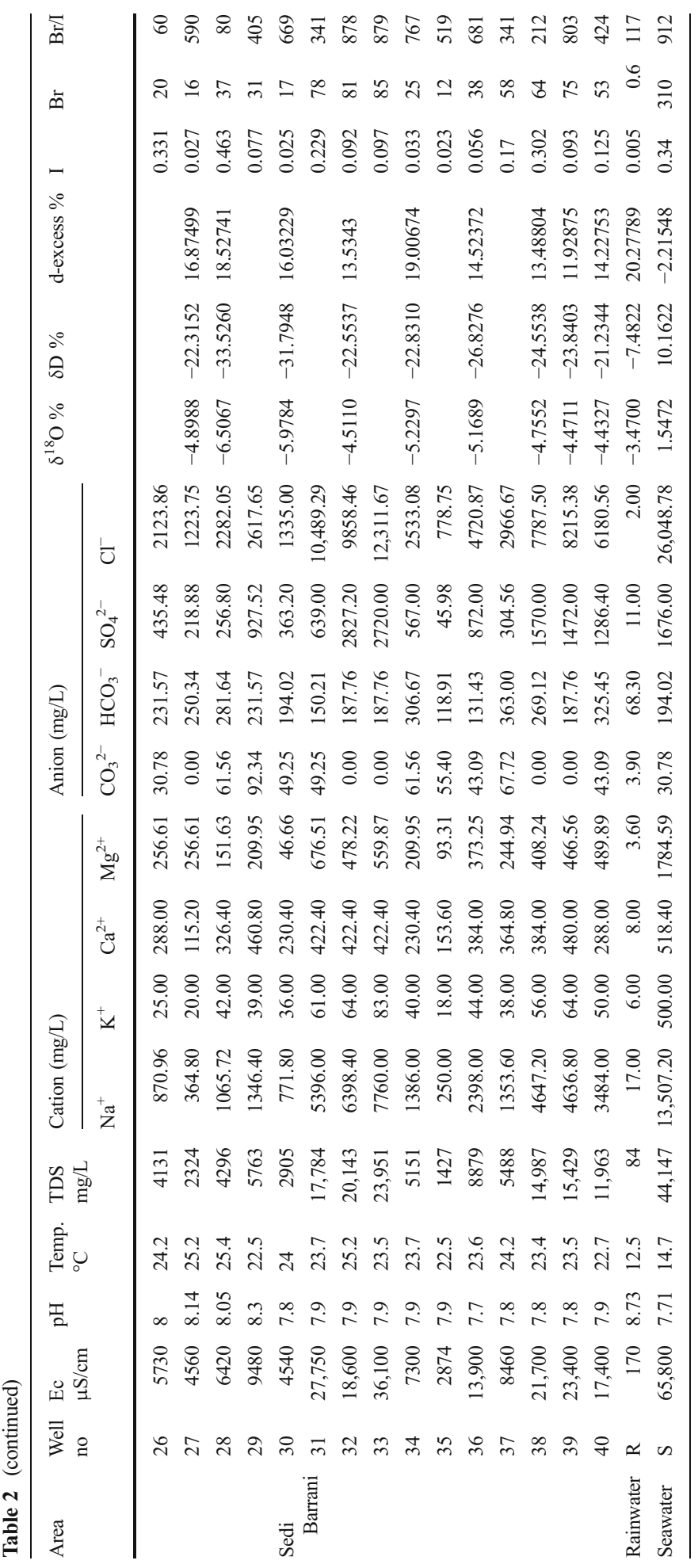


a
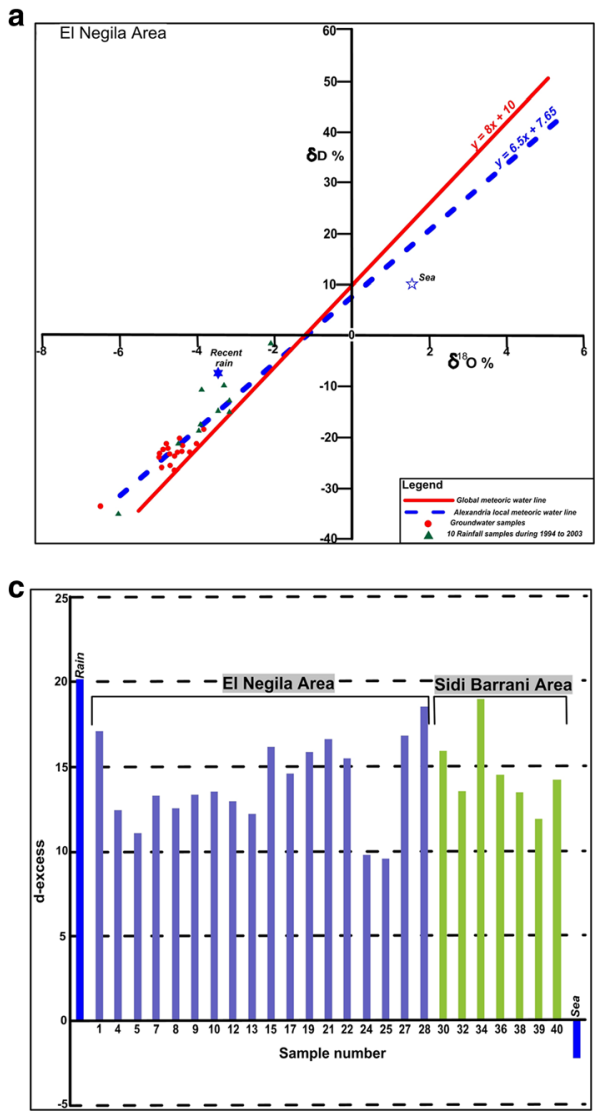

b

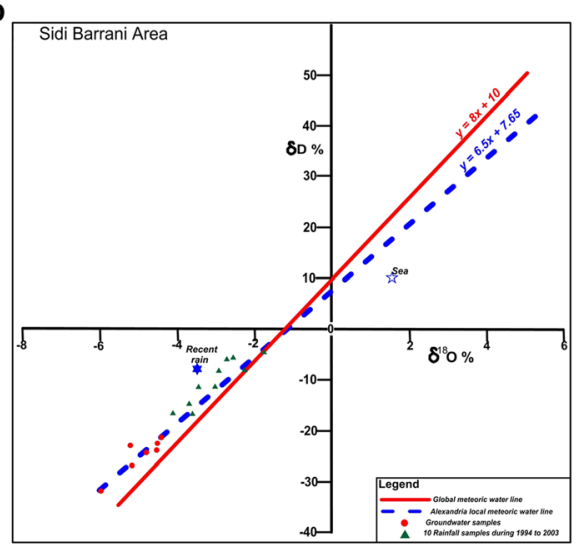

d

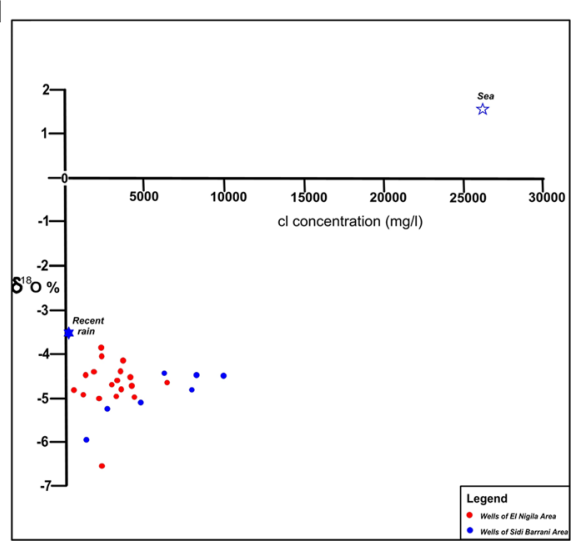

Fig. 9 Different plots to interpret the data of isotope analyses. (a) and (b) Plot of $\delta^{18} \mathrm{O} \%$ - $\delta \mathrm{D} \%$ for the studied groundwater samples in El Negila and Sidi Barrani areas, with Global Meteoric Water Line (MMWL) and Alexandria local Meteoric Water Line (ALMWL); (c) Histograms show the D-excess values of the studied groundwater samples in comparison with values of sea and rainwater; (d) Plot shows the relationship between $\delta^{18} \mathrm{O} \%$ and chloride concentration

In addition, the enrichment factor (EF) is calculated to show the degree of enrichment of a given element $(\mathrm{Mg}$ and $\mathrm{Na}$ ) compared to the relative abundance of the element in seawater (Table 3). Therefore, the groundwater samples of the karst aquifer have enrichment factors more than 1 for $\mathrm{Mg}$ element and near 1 (only 10 samples below 1) for Na element. These results clarify the impact of rock-water interactions where the water bearing formation is composed mainly of limestone and dolomitic limestone. The plot of concentration ratios of $\mathrm{Cl}$ versus the enrichment factor of $\mathrm{Na}$ and $\mathrm{Mg}$ elements (Fig. 11) shows the rare influence of mixing rate of seawater whereas the carbonate or terrestrial materials have effective contributions in the karst groundwater chemistry.

\section{Discussion}

The hydrogeologic setting of the karst aquifer in the study area indicates more favourable conditions for groundwater occurrence because it receives amounts of annual rainfall which 
a

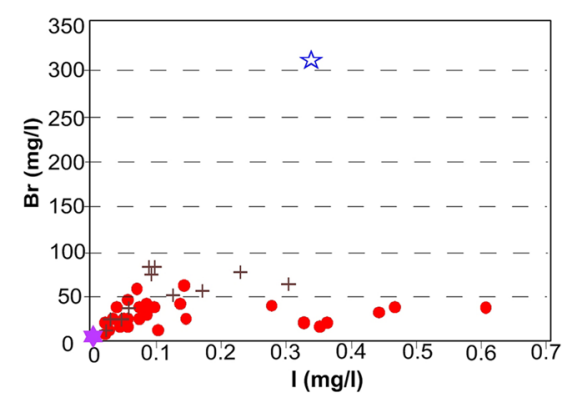

C

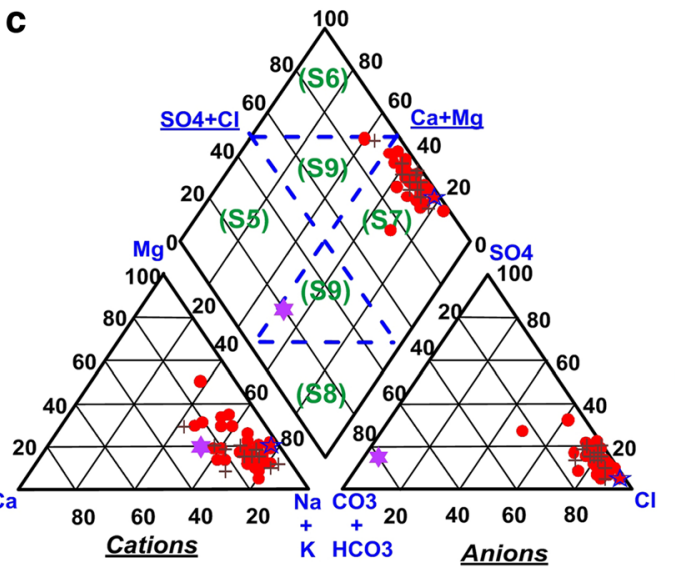

Legend

- Groundwater samples of El Negila area Rainfall sample from the area of study (R)

+ Groundwater samples of Sidi Barrani area

Sub-area (S7): The non-carbonate alkali exceeds $\mathbf{5 0} \%$ Sub-area (S9): No one cation-anion pair exceeds $\mathbf{5 0} \%$.

Fig. 10 Geochemical representation of the chemical analyses of the studied water samples. a Relationship between iodide $\left(\Gamma^{-}\right)$and bromide $\left(\mathrm{Br}^{-}\right)$concentrations; b Relationship between chloride $\left(\mathrm{Cl}^{-}\right)$and sodium $\left(\mathrm{Na}^{+}\right)$ concentrations; c Distribution of the studied groundwater samples on Piper diagram

provide the opportunity of recharge of the karst aquifer, and thus, the sustainability of the groundwater is applicable. The karst aquifer (Middle Miocene aquifer) in the study area is built up mainly of fissured and cavernous limestone, with clay and marl intercalations. Principally, the structural setting can be considered the main factor which controls the groundwater occurrence in the studied aquifer. The fracture systems are well pronounced around the headlands in the two pilot areas (Fig. 4a and b) and are responsible for the development of the drainage channels (Fig. $6 \mathrm{~b}$ and e), as confirmed from the spot images where zone B in El Negila area (Fig. 5a) has no drainage lines with rare structure lineaments. In El Negila area, 8 headlands were recorded along the Mediterranean coast (Fig. 5a), which have resulted from the regional structures (folding), accompanied by groups of fractures which lead to groundwater occurrences and its recharge. A great number of drainage channels are dissecting the tableland in El Negila area. The number of drainage lines is decreased in Sidi Barrani area. These channels are structurally controlled and well developed in areas where lineaments of weakness are common (compare between Figs. 4 and 6). The annual rainwater flows to the north and partially toward the east-north of the study area, following the regional topography of the 
Table 3 Concentration rate (CR) and Enrichment factor $(\mathrm{EF})$ relative to chloride of sea water

\begin{tabular}{|c|c|c|c|c|c|}
\hline Area & Well no. & $\begin{array}{l}\text { Concentration }(\mathrm{mg} / \mathrm{L}) \\
\mathrm{Cl}^{-}\end{array}$ & $\begin{array}{l}\mathrm{CR} \\
\mathrm{Cl}^{-}\end{array}$ & $\begin{array}{l}\mathrm{EF} \\
\mathrm{Na}^{+}\end{array}$ & $\begin{array}{l}\mathrm{EF} \\
\mathrm{Mg}^{2+}\end{array}$ \\
\hline Seawater & $\mathrm{S}$ & 26,049 & 1.00 & 1 & 1 \\
\hline \multirow[t]{29}{*}{ El Negila } & 1 & 578.50 & 0.02 & 1.8 & 7.6 \\
\hline & 2 & 890.00 & 0.03 & 1.2 & 6.3 \\
\hline & 3 & 2225.00 & 0.09 & 1.1 & 3.8 \\
\hline & 4 & 2225.00 & 0.09 & 1.1 & 4.0 \\
\hline & 5 & 2288.57 & 0.09 & 1.0 & 5.4 \\
\hline & 6 & 2415.71 & 0.09 & 1.1 & 4.6 \\
\hline & 7 & 1891.25 & 0.07 & 1.4 & 1.2 \\
\hline & 8 & 3382.00 & 0.13 & 1.1 & 4.3 \\
\hline & 9 & 4034.67 & 0.15 & 1.0 & 3.3 \\
\hline & 10 & 3233.67 & 0.12 & 1.0 & 3.1 \\
\hline & 11 & 6544.12 & 0.25 & 1.1 & 3.1 \\
\hline & 12 & 6334.71 & 0.24 & 1.1 & 2.9 \\
\hline & 13 & 2898.86 & 0.11 & 1.1 & 3.0 \\
\hline & 14 & 2510.26 & 0.10 & 1.1 & 2.6 \\
\hline & 15 & 4272.00 & 0.16 & 1.2 & 3.3 \\
\hline & 16 & 4450.00 & 0.17 & 1.1 & 3.0 \\
\hline & 17 & 4120.37 & 0.16 & 0.8 & 6.1 \\
\hline & 18 & 1223.75 & 0.05 & 0.8 & 6.2 \\
\hline & 19 & 3640.91 & 0.14 & 0.8 & 6.6 \\
\hline & 20 & 7067.65 & 0.27 & 1.1 & 2.1 \\
\hline & 21 & 2132.29 & 0.08 & 0.8 & 6.9 \\
\hline & 22 & 1335.00 & 0.05 & 1.1 & 9.2 \\
\hline & 23 & 1068.00 & 0.04 & 1.0 & 4.4 \\
\hline & 24 & 3625.93 & 0.14 & 0.9 & 5.8 \\
\hline & 25 & 3178.57 & 0.12 & 1.0 & 4.6 \\
\hline & 26 & 2123.86 & 0.08 & 0.8 & 6.1 \\
\hline & 27 & 1223.75 & 0.05 & 0.6 & 10.5 \\
\hline & 28 & 2282.05 & 0.09 & 0.9 & 3.3 \\
\hline & 29 & 2617.65 & 0.10 & 1.0 & 4.0 \\
\hline \multirow[t]{11}{*}{ Sedi Barrani } & 30 & 1335.00 & 0.05 & 1.1 & 1.8 \\
\hline & 31 & $10,489.29$ & 0.40 & 1.0 & 3.2 \\
\hline & 32 & 9858.46 & 0.38 & 1.3 & 2.4 \\
\hline & 33 & $12,311.67$ & 0.47 & 1.2 & 2.3 \\
\hline & 34 & 2533.08 & 0.10 & 1.1 & 4.2 \\
\hline & 35 & 778.75 & 0.03 & 0.6 & 6.0 \\
\hline & 36 & 4720.87 & 0.18 & 1.0 & 4.0 \\
\hline & 37 & 2966.67 & 0.11 & 0.9 & 4.1 \\
\hline & 38 & 7787.50 & 0.30 & 1.2 & 2.6 \\
\hline & 39 & 8215.38 & 0.32 & 1.1 & 2.9 \\
\hline & 40 & 6180.56 & 0.24 & 1.1 & 4.0 \\
\hline
\end{tabular}



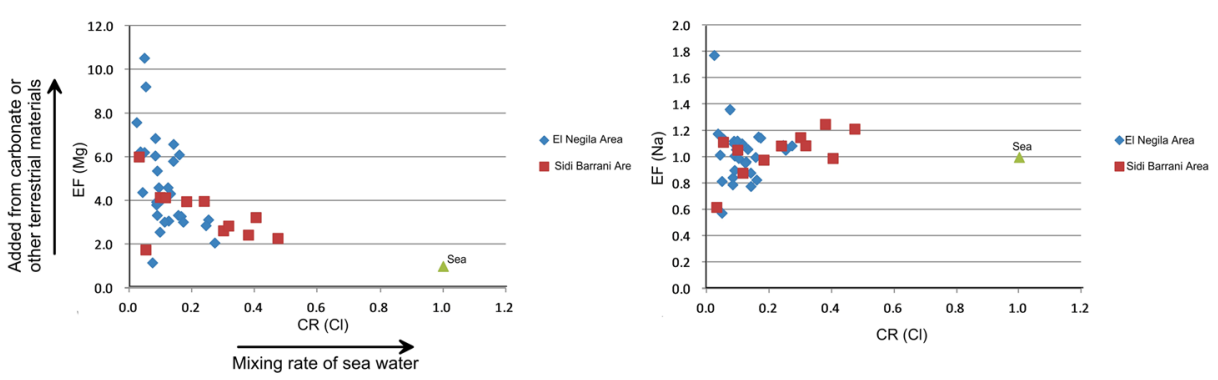

Fig. 11 The concentration ratio of $\mathrm{Cl}^{-}$versus enrichment factor of $\mathrm{Mg}^{2+}$ and $\mathrm{Na}^{+}$

surface (Fig. 6c and f). The slope plays a significant role in the amount of infiltration compared to runoff, with infiltration being inversely related to slope. Therefore, a portion of the rainwater is thought to be infiltrated through joints and fractures and recharge the karst aquifer; this can be considered the hypothesis of the present study. The isotope analyses confirmed this hypothesis because they indicate that most of the groundwater was resulted from a mixing between recent and older recharge. The groundwater from the study area shows nearly similar isotopic compositions, suggesting similar recharge conditions. Accordingly, the groundwater of karst aquifer is derived from rainwater and the recharging source is the precipitation in the study area. Also, the d-excess of the groundwater samples support this interpretation; it has been suggested that low d-excess values around $10 \%$ indicate paleo-recharge, while higher $\mathrm{d}$ excess values $(>20 \%)$ indicate modern-day recharge (Vengosh et al. 2007). The d-excess (Fig. 9c) for the samples of the karst aquifer in both pilot areas indicates that the groundwater has paleo and modern recharge from rainfall under different climatic conditions. This groundwater has d-excess values mainly more than that of the global meteoric water line (GMWL; Craig 1961; d-excess $=10 \%$; accordingly, the groundwater of the karst aquifer is of meteoric origin that flushed. This interpretation is also confirmed by the ratios $\left(\Gamma / \mathrm{Br}^{-}\right)$of the studied groundwater, which are compared to the ratios of sea and rain values, and also reflect that the groundwater mineralization of the karst aquifer is of meteoric origin. The chemical
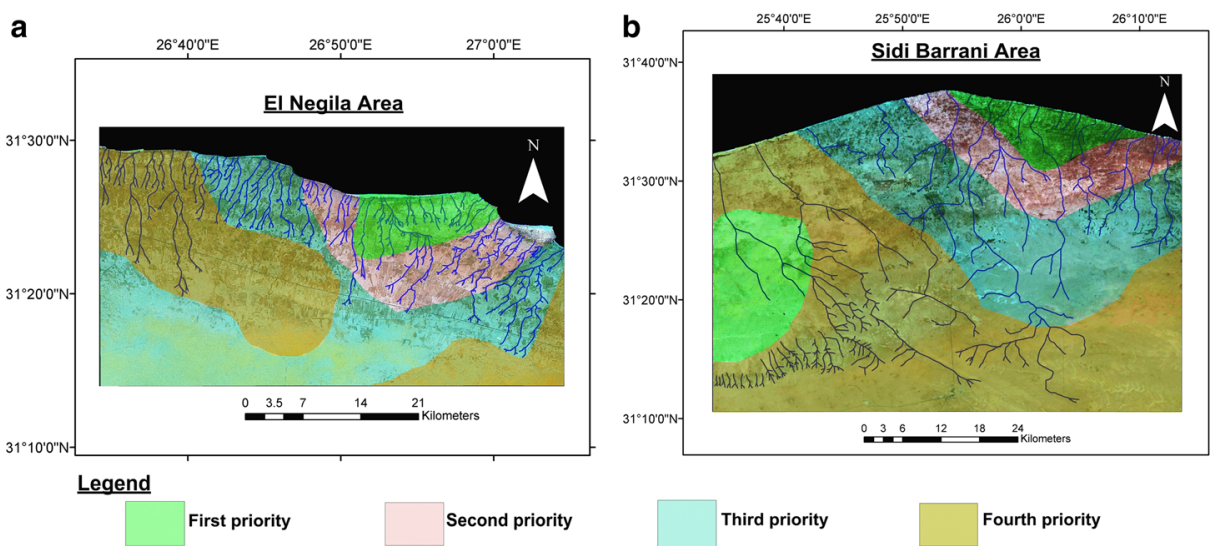

Fig. 12 Priority maps for hydro-geophysical studies of the karst aquifer in El Negila area. a and Sidi Barrani area; b Northwestern coast of Egypt. The priority is based on the data layers which include density of structural lineaments, frequency of structural lineaments, slope degree, drainage lines, TDS values of the existed wells and values of the total precipitation 
composition of the karst groundwater is a combined result of water constituents. As groundwater flows through, it reacts with minerals present in the aquifer matrix that may modify its composition. The high salinity values of the studied groundwater in both pilot areas could be attributed to the leaching processes, as the water bearing rock formation is made of carbonate rocks (limestone and dolomitic limestone with clay and marl intercalations). The dissolved salts are derived from reactions of groundwater with aquifer rocks. The groundwater of karst aquifer shows enrichments of three major constituents: $\mathrm{Na}^{+}, \mathrm{Ca}^{2+}$ and $\mathrm{Mg}^{2+}$. These are attributed to dissolution of carbonate rocks encountered along the flow path of groundwater, which is enhanced by the increase of temperature in the study area. The dissolution of $\mathrm{Ca}^{2+}$ and $\mathrm{Mg}^{2+}$ minerals, such as calcite and dolomite, occurs, with sources of these elements the Middle Miocene rocks. The enrichment in $\mathrm{Mg}^{2+}$ may indicate that some of the excess of $\mathrm{Ca}^{2+}$ is derived mainly from the dissolution of dolomite. The enrichments of $\mathrm{Na}^{+}$and $\mathrm{Mg}^{2+}$ increase the salinity of all groundwater samples, which is mainly attributed to the dissolution processes of salts rich in $\mathrm{Na}^{+}$and $\mathrm{Mg}^{2+}$. This does not exclude the contribution of $\mathrm{CO}_{2}$ gas and longer residence time, and influence of salty water and cation exchange processes where the precipitated rainwater causes leaching and dissolution of the tableland, and consequently, groundwater salinity increases in the coastal plain area and in the downstream portions of the drainage lines. The presence of carbonate $\left(\mathrm{CO}_{3}\right)$ and bicarbonate $\left(\mathrm{HCO}_{3}\right)$ reflect the dilution effect of rainwater on groundwater. Also, it is noted, that the karst aquifer has excessive withdrawal for agricultural purposes; it is thought that this withdrawal exceeds the current recharges, and accordingly, it may lead to the increase in water salinity. This means that the human activities have an impact on water quality.

The investigation of the karst aquifer in the two pilot areas provided many data layers which indicate that some specific regions have more favorable conditions for groundwater recharge and should be subjected to hydro-geophysical exploration (Fig. 12a and b). The priority is based on the data layers, which include: density of structural lineaments, frequency of structural lineaments, slope degree, drainage lines, TDS values of the existing wells, and values of the accumulated precipitation. The areas of first priority have more intense structural lineaments, low slope, and represent the downstream part of drainage basins, conditions presenting opportunity for recharge of the karst aquifer through the fractures. Also, some of the drilled wells in the first and second priority areas have low TDS (e.g., wells with numbers. 1, 2, 27 in El Negila area, and 35 in Sidi Barrani area), while the others wells in the same areas show high TDS. This can be attributed to the locations of the wells where the drilling in sites located along or beside the fractures can receive increased amount of recent recharge through the rainfall, and accordingly, decrease the groundwater salinity. On the other hand, the depression located to the west of Sidi Barrani area has special conditions. Many hydrographic channels are draining to this depression, with one of them elucidated from the spot image in Fig. 5b. The surface of this depression is covered by undifferentiated Quaternary deposits, which are mainly nonconsolidated sediments; therefore, they facilitate the recharge process. One drilled well (well no. 30) was recorded in this depression where the measured TDS concentration reached $2905 \mathrm{mg} / \mathrm{L}$. According to these conditions, this depression is also given a first priority, although rare structure lineaments were recorded. The hydro-geophysical studies should continue according to the priority degrees to determine the best sites for future exploration.

\section{Conclusions}

The current study represents an integrated approach to investigate the karst aquifer and clarify the factors which affect the occurrence and quality of its water. This approach was achieved in 
a data scarce arid region. Although the study area falls in the arid zones, it receives amounts of annual rainfall which provide the opportunity to recharge the karst aquifer, and thus, the sustainability of its groundwater is applicable. The karst aquifer is built up mainly of fissured and cavernous limestone, with clay and marl intercalations. Principally, the structural setting can be considered as the main factor which controls the groundwater occurrence in this aquifer. The main hypothesis of this study is based on that a portion of rainwater is thought to be infiltrated to the groundwater through joints and fractures, and recharge the karst aquifer. In this regard, the isotopes analyses were effective tool to confirm this hypothesis where they indicate that most of the groundwater has resulted from a mixing between recent and older recharge. In addition, the use of the ratios $\left(\Gamma / \mathrm{Br}^{-}\right)$of the groundwater samples, in comparison with the ratios of sea and rain values, clarified the groundwater mineralization and its origin. The investigation of the karst should be initially based on multi data layers, which include: density of structural lineaments, frequency of structural lineaments, slope degree, drainage lines, TDS values of the existing wells, and values of the accumulated precipitation. These hydrogeologic layers enable the current paper to clarify the factors which affect the occurrences and quality of the groundwater in the karst aquifer under arid environment. Therefore, this scientific approach can be implemented in any arid coastal area under the same conditions. It was shown clearly in this study that remote sensing and GIS can provide the appropriate platform for convergence of different data obtained from multidisciplinary researches as well as field investigations.

Acknowledgments The authors are thankful to the MIF (Matsumai International Foundation, Tokyo, Japan) who provide a postdoctoral scholarship of the first author, to carry out researches in the University of Tokyo. Many thanks for the anonymous reviewers and the editor-in-chief; their valuable comments helped to improve the earlier versions of this paper.

\section{References}

Abdel Mogheeth S (1968) Sedimentology, geochemistry and evaluations of the Marmarica limestone, Western Desert, Egypt, Ph.D. Dissertation, Fac. Sci. Al Azhar University

Ali AO, Rashid M, El Naggar S, Abdul Al A (2007) Water harvesting options in the drylands at different spatial scales. Land Use Water Resour Res 7:1-13

ASTM (2002) Water environmental technology Annual book of American Society of Testing and Materials standards, sec. 11.01 and 11.02, West Conshohocken, U.S.N

Atwa SM (1979) Hydrology and hydrogeochemistry of the Northwestern Coast of Egypt. PhD. Dissertation, Fac. Sci., Alexandria University

Awad MA, Hammad FA, Aly AI, Sadek MA (1994) Use of environmental isotopes and hydrochemistry as indicators of groundwater resources in El-Dabaa area, Northwestern coastal zone of Egypt. J Environ Geochem Health 16(1):31-38

Ball J (1939) Contribution to the geography of Egypt. Surv Dept Publ, Cairo

Conoco (1986) Geological map of Egypt, scale 1:500,000 GPC, sheets no. NH35NE

Craig H (1961) Isotopic variations in meteoric waters. Science 133:1702-1703

Dansgaard W (1964) Stable isotopes in precipitation. Tellus XVI:436-468

Duce RA, Hoffman GL, Zoller WH (1975) Atmospheric trace metals at remote northern and southern hemisphere sites: pollution or natural? Science 187:339-342

El Raey M (1998) Framework of Integrated Coastal Area Management of the Fuka-Matrouh area, Egypt, PAP/ RAC-37

El Senussi MY, Shata A (1969) Geomorphological and morphological aspects of Umm El Rakham. Bull Inst Desert 19(z):1-32, Cairo, Egypt

El Shamy I (1968) The geology of soil and water resources in El Daba'a area. M.Sc. Thesis, Fac. Sc., Cairo University

El Shazly MM (1964) Geology, pedology and hydrogeology of Mersa Matruh area, Western Mediterranean littoral, U. A. R., Ph.D. Dissertation, Fac. Sci., Cairo University 
El Shazly M (1972) Contribution to the geochemistry of the groundwater in Mersa Matruh area, Western Mediterranean Coastal Zone, Egypt. Desert Inst Bull XX(2):289-300

El Shazly M, Shata A (1971) Geomorphology and pedology of Mersa Matrh area "Western Mediterranean Littoral Zone". Desert Inst Bull XIX(1):1-28

Embaby AA, Shanab SE (2012) Geochemistry of quaternary aquifer groundwater in burg El Arab area and its suitability for irrigation. J Am Sci 8(12):1366-1377

FAO (1989) Arid zone forestry: A guide for field technicians. FAO Conservation Guide, http://www.fao.org/ docrep/T0122E/T0122E00.htm

Foody G, Ghoneim E, Arnell N (2004) Predicting locations sensitive to flash flooding in an arid environment. J Hydrol 292:48-58

Ghoneim E (2008) Optimum groundwater locations in the northern United Arab Emirates. Int J Remote Sens 29(20):5879-5906

Ghoneim E, Foody G (2012) Assessing flash flood hazard in an arid mountainous region. Arab J Geosci. doi:10. 1007/s12517-011-0411-7

Hammad FA (1966) The geology of water supplies in Ras El Hekma area. M.Sc. Thesis, Fac. Sci., Cairo University

Hammad FA (1972) The geology of soils and water resources in the area between Ras El Hekma and Ras El Rum (Western Mediterranean Littoral Zone, Egypt). Ph.D. Dissertation, Fac. Sci., Cairo University

Hammad FA, Taha AA, Shata AA (1986) The study of landforms in the area between Ras El Hekma and Ras Alm El-Rum (Northwestern Mediterranean littoral zone, Egypt). Bull Fac Sci 13(1):189-210, Mansoura University

International Association of Hydrogeology (IAH), (2009) Karst Aquifer http://www.iah.org/karst/karst hydrogeology.html. Accessed 15 March 2014

International Atomic Energy Agency, "IAEA" (2004) Isotope Hydrology Information System. The ISOHIS Database. http://isohis.iaea.org/. Accessed 1 March 2014

Jensen SK, Domingue JO (1988) Extracting topographic structure from digital elevation model data for geographic information system analysis. Photogramm Eng Remote Sens 54:1593-1600

Lloyd JW (1997) The future use of aquifers in water resources management in arid areas. Arab J Sci Eng 22(IC): 33-45

Maidment DR (2002) Arc Hydro GIS for water resources. ESRI press, Redlands

Mediterranean Groundwater Report (M.G.R.), (2007) Technical report on groundwater management in the Mediterranean and the Water Framework Directive http:/www.semide.net/initiatives/medeuwi/JP/ GroundWater. Accessed 5 March 2014

Misak R (1974) Geomorphology and geology of the area between El Daba'a and Ras El Hekma, Western Mediterranean coastal zone, Egypt. M.Sc. Thesis, Ain Shamas University

Mousa BM (1976) Geomorphology and subsurface geology of the area between El Alamein and Qattara Depression, Northern Western Desert, Egypt. M.Sc. Thesis, Fac. Sci., Ain Shams University

Pautsch GR, Abdelrahman AH (1998) Effects of Egyptian economic reforms: the horticultural sector. Food Policy 23(2):199-210

Paver GD, Protorius DA (1954) Report on the reconnaissance of hydrogeological investigation in the western Desert Coastal Zone. Bull. Sci., Des., Inst., 1-145

Piper AM (1944) A graphic procedure in the geochemical interpretation of water analyses. Trans Am Geophy 6 : 914-923, Union, 25, Washington DC

Raslan SM (1995) Geomorphological and hydrogeological studies on some localities along the Northwestern Coast of Egypt, M. Sc. Thesis, Faculty of Science, Menoufia University

Rizk ZE (1982) Geological and hydrogeological studies on the North Wetern coast of Egypt.” Unpubl. M.Sc. Thesis, Fac. Sci., Menofia University

Said R (1962) Geology of Egypt, First edition. Elsevier Science, Cairo

Said R (1990) The Geology of Egypt. Balkema, Rotterdam

Salem AA, Mohamed AH (2011) Hydrogeological studies of the groundwater aquifers in El Sallum depression, Northwestern coast, Egypt. Sedimentol Egypt 19:97-112

Selim AA (1969) Geology of El-Salum area. Ph.D. Dissertation, Faculty of Science, Alexandria University

Shata A (1953) New light on the structural development of the western. Bull Inst Desert Egypt 3(1):101-106, Desert, Egypt

Shata A (1955) An introductory note on the geology of the northern portion of the Western Desert of Egypt. Bull Inst Desert 5(2):96-106

Shata A (1957) Geology and geomorphology of Wadi El Kharrupa area. Bull Inst Desert 10:91-120

UNESCO (1977) Climatic zonation of the arid and semi-arid regions. In: REij, C., Mulder, P. and Begemann, L (1988). Water harvesting for plant production. Technical paper no. 91, The World Bank, Washington, D.c. UNEP/GRID

Vengosh A, Hening S, Ganor J, MayerB WCE, Bullen TD, Paytan A (2007) New isotopic evidence for the origin of groundwater from the Nubian Sandstone Aquifer in the Negev, Israel. App Geochem 22:1052-1073 
Yousif M (2014) Integration of the geomorphologic and geologic studies for water potentialities development in El Zarraqa and El Harraqa basins, East Matrouh, northwestern coast, Egypt. Arab J Geosci. doi:10.1007/ s12517-014-1522-8

Yousif M, Bubenzer O (2013a) An integrated approach for groundwater assessment at the Northwestern Coast of Egypt (Ras El Hekma area): case study. Springer Environ Earth Sci 69(7):2227-2246

Yousif M, Bubenzer O (2013b) Integrated remote sensing and GIS for surface water development. Case study: Ras El Hekma area, northwestern coast of Egypt. Arab J Geosci 6(4):1295-1306

Yousif M, Oguchi T, Anazawa K, Ohba T (2014) Geospatial information and environmental isotopes for hydrogeological evaluation: Ras Alam El Rum Northwestern coast of Egypt. Nat Resour Res. doi:10. 1007/s11053-014-9252-x 